Article

\title{
Energy as a Factor of Investment Attractiveness of Regions for Agricultural Enterprises
}

\author{
Hanna Godlewska-Majkowska ${ }^{1}$ (D) and Agnieszka Komor ${ }^{2, *}$ (D) \\ 1 Institute of Enterprise, Collegium of Business Administration, Warsaw School of Economics, \\ 02-554 Warszawa, Poland; hgodle@sgh.waw.pl \\ 2 Department of Management and Marketing, Faculty of Agrobioengineering, University of Life Sciences in \\ Lublin, 20-950 Lublin, Poland \\ * Correspondence: agnieszka.komor@up.lublin.pl; Tel.: +48-81-461-0061
}

Citation: Godlewska-Majkowska, H.; Komor, A. Energy as a Factor of Investment Attractiveness of Regions for Agricultural Enterprises. Energies 2021, 14, 2731. https://doi.org/ $10.3390 /$ en14092731

Academic Editors: Piotr Gradziuk, Bogdan Klepacki, Mariusz J. Stolarski and Josef Maroušek

Received: 10 March 2021

Accepted: 7 May 2021

Published: 10 May 2021

Publisher's Note: MDPI stays neutral with regard to jurisdictional claims in published maps and institutional affiliations.

Copyright: (c) 2021 by the authors. Licensee MDPI, Basel, Switzerland. This article is an open access article distributed under the terms and conditions of the Creative Commons Attribution (CC BY) license (https:/ / creativecommons.org/licenses/by/ $4.0 /)$.

\begin{abstract}
The aim of the article is to identify and assess the relationship between the investment attractiveness of regions for agricultural enterprises and the energy factor. Classical theories of the location of agriculture emphasise the importance of the market factor. The energy factor has so far been ignored, despite the global trend related to the increasing importance of production scales and rising energy consumption in agriculture. There are also no methodological proposals that allow a comprehensive assessment of the investment attractiveness of regions for agricultural enterprises, taking into account the leading location factors. The article presents the author's methodological model based on the weight-correlation method of valorisation of investment attractiveness of regions for economic entities that invest in agricultural production. It contains a sub-aggregate describing the energy factor. This proposal is a contribution to the theory of the location of agriculture in the field of location factor analysis. The developed methodological model is used to explain location decisions of agricultural enterprises at the regional level. Access to energy as well as energy management increase locational advantages and reduce the economic risk of carrying out agricultural activities in economic units, which contributes to an increase in the sustainability of agricultural production. This is especially true in areas dominated in the past by state-owned and cooperative enterprises, which are the dominant group of enterprises in this area after privatization. The proposed methodology was positively verified on the example of Polish regions, as a significant influence of the energy factor on investment attractiveness at the local level was demonstrated.
\end{abstract}

Keywords: investment attractiveness of regions; energy; agriculture; economic entities; sustainability

\section{Introduction}

Investment attractiveness of regions has been a subject of interest for researchers dealing with the analysis of locational advantages of potential industrial or service investment locations. Papers that take into account the location needs of enterprises, whose main economic activity is agricultural production, are rarely published.

The need for studies on this subject arises from changes in the ownership structure within the agricultural sector, as individual farms are falling out of land use. This is linked to an ageing population in rural areas. Migration of the rural population to cities causes succession problems in regard to individual farms. This gives rise to a farmland trade.

A second reason for the legitimacy of undertaking studies on this subject is the privatisation of former state farms and agricultural cooperatives. Privatised farms of this type manage their estates according to changes in the market for agricultural and food products. For this reason, there is an emerging offer of real property in rural areas that can be the subject of location decisions by agricultural enterprises.

Agricultural enterprises can achieve competitive advantages in the form of low business costs and can also compete with high product quality. One of the most important elements influencing the possibility of obtaining competitive advantages by these units is 
the lack of interference in the course of operational processes. The course is the result of numerous elements of a technical and organisational nature. The energy factor plays a fundamental role among them. This is shown by the $12.9 \%$ increase in energy use in agriculture and forestry in the EU 28 countries over the period 2009-2018, based on EUROSTAT data. It was particularly high in Germany, United Kingdom, Albania, Romania, and Hungary. In Poland, this increase reached $9.7 \%$ of the 2009 value. Agricultural enterprises achieve economies of scale and diversity benefits through the use of modern technologies. Therefore, the process of selecting the location of agricultural enterprises should be considered in an analogous way to the location analysis of industrial and service enterprises.

It is worth noting that, nowadays, investment activity is a prerequisite for increasing the competitiveness of agricultural production, increasing its innovativeness, increasing its export potential, low-carbon emissions, and climate neutrality, thus contributing to the development of the bioeconomy in the area. Investments by agri-enterprises can thus, in the long term, support the socioeconomic development of areas traditionally relying on the agricultural sector in order to ensure sustainable regional and local development.

The Polish regions can serve as an example of a location environment for agricultural enterprises representative of other countries and regions in Central and Eastern Europe. Following the privatisation of state or cooperative farms, opportunities are being sought to improve the functioning of agriculture by, among other things, introducing the principle of spatial order, according to which the right activity should be located in the right place. Regions with a strong agricultural function can therefore be included in the location analysis, not only for the domestic real estate market, but also for foreign investors. Therefore, the study of locational determinants of agricultural enterprises is a research gap that the authors of this study wish to fill.

The goal of this paper was to identify and assess the relationship between the investment attractiveness of regions for agricultural enterprises and the of energy factor.

The following research hypothesis was verified in the process of execution of the above mentioned goal: there is a positive relationship between the energy factor and the investment attractiveness of regions for enterprises from Section A (agriculture, forestry, and fishing) (H1).

The specific objectives are as follows:

1. Identification of the essence of investment attractiveness of regions in the light of literature, with particular emphasis on the investment attractiveness of regions for agricultural enterprises (O1).

2. Development of a methodological model for evaluating investment attractiveness of regions for Section A enterprises (agriculture, forestry, hunting, and fishing), taking into account the energy factor $(\mathrm{O} 2)$.

The paper poses the following research questions related to the specific objectives:

I. How is the specificity of investment attractiveness of regions for agricultural enterprises (Section A) expressed?

II. How can the investment attractiveness of regions be evaluated for investments by economic entities from Section A, taking into account the energy factor?

\section{Literature Review}

\subsection{Theories of Agricultural Location and Current Trends in Practice}

The theoretical basis for analysing the distribution of agricultural production is contained in the pioneering work of Johann Wolfgang von Thünen [1]. According to the agricultural location theory formulated by the author, commodity agricultural production was concentrated in the form of concentric rings around a market formed by a large city. The rings were characterised by production specialisation determined by the amount of the land rent, which was the resultant of transport costs and the difference between the unit price of a given agricultural product and its unit production cost [2]. Due to the limited shelf life of fruit and milk, which was reflected in high transport rates, this type of production was located close to the market. While extensive livestock production occupied 
areas further afield, representing the outermost ring of agricultural production. It is worth noting that, according to the theory, the forest ring was closest to the town due to the fact that in the 18th century firewood was the main energy resource. The disadvantage of this model is that it assumes that the space is homogeneous and isotropic, whereas in reality it is heterogeneous. Therefore, the author applied a modification of his model, extending the range of zones in that part of the suburban zone where areas with above-average soil values occurred, as assumed. However, one can agree with U. Mäki that J. H. von Thünen was a realist who deliberately used unrealistic assumptions to pursue a truthful account of an important aspect of determining agricultural land use patterns [3].

This model, despite being developed at the end of the 18th century, is an interesting starting point for a contemporary explanation of the relationship between the distribution of agricultural enterprises and the locational pattern of large markets. Although a long time has passed since this theory was formulated, it can be noted that to this day the presence of large markets influenced the distribution of agricultural commodity production [4].

The theory of rings has been the basis for the development of numerous theoretical modifications aimed at explaining the regularities of agricultural development and distribution, as well as other economic theories [5]. An example of such approaches may be, for example, the Sinclair's inverted food rings models [6], according to which production results and productivity per unit area increase with distance from the city. At the same time, the value of agricultural land near cities is inversely proportional to its market price [7]. It is also important that industrialisation contributes to the contamination of food produced in suburban areas. It was therefore suggested that a forest ring should be maintained around the town, followed by a strip of meadow and pastureland for grazing animals. The suburban forest belt can also act as a local forest landscape with cultural value for the community living in large cities [8].

The theory of rings, although it originated from observations made in southern Germany, has gained universal value because the actual spatial structures of agricultural production were formed according to this model. This is evidenced, for example, by the very frequent direction of special agricultural production in the form of greenhouse cultivation of vegetables, fruits, and flowers in the suburban zone. To this day, provision zones can still be seen around large cities [9], resulting from the desire to compete on the quality of agricultural products for direct consumption by the inhabitants of large cities. The significant influence of large and spatially concentrated markets on the location of the agricultural commodity sector has therefore been maintained. However, it should be noted that in agriculture the outlets created by the processing industry as well as by wholesale trade (for example, commodity exchanges) are also important [10]. Consequently, the distribution of agricultural enterprises is influenced by the spatial arrangement of outlets created in all three of their types mentioned above.

A prerequisite for obtaining the benefits of proximity to markets is communication accessibility for agricultural enterprises, as well as a sufficiently high level of production concentration to obtain economies of scale in production and rationalisation of energy management. The proximity of markets does not exclude multiple transports of agricultural raw materials to urban food processing plants, nor does it eliminate the need for multiple transports of food delivered to residents or other customers forming the first tier of supply chains [11].

The organisation of transport also brings with it the issue of energy efficiency. The location of agricultural enterprises is linked to the energy factor not only because of the need to secure the energy needs of the enterprise, but also has an impact on rationalising the use of fuels necessary for organising the transport of both raw materials and products. Furthermore, from the point of view of the public good, the energy aspects of losses and damage to raw materials and agricultural products caused by the irrational organisation of shipping or transport arrangements must be taken into account. The resulting losses and damages during transport are a waste of the energy that was used to produce them [12]. Therefore, when considering the energy determinants of the location of agricultural en- 
terprises, account must be taken not only of ensuring a sufficient supply of energy, but also of reducing the various sources of energy wastage. In developing countries, it is also important to streamline energy management and exploit all opportunities to obtain additional energy sources. For example, the use of digestate from biogas plants helps to reduce energy consumption in the production of certain industrial products in developing countries, such as cement, which also has a positive impact on energy management and helps to reduce the impact on the natural environment [13].

The locational advantages relevant for agricultural enterprises have another context related to energy management. In addition to the already mentioned great importance of access to energy supply and energy savings in the logistical sphere, it is worth mentioning the energy savings resulting from closed-loop energy management. The opportunities in this regard are related to the use of production waste or agricultural by-products for energy purposes. Products hitherto regarded as sources of environmental pollution can be used as sources of energy, especially heat. These include, for example, manure, slurry, straw, and other by-products generated in agriculture. Another possibility is to produce energy from purpose-grown phytomass, which has a rapid growth rate [14]. They can be a source of energy for the distributed energy system.

With this solution, it is possible to reduce the consumption of energy in agricultural production, as well as to reduce the nuisance to the natural environment resulting from the activities of agricultural enterprises. The closed loop circuit applied to electricity management is an element, which will allow for greater self-sufficiency on the part of agricultural enterprises, provided that they can be integrated into the national or regional energy system. The electricity from biogas combustion creates an additional source of income. This is especially important in developing countries [15].

It is worth noting that initiatives to prevent waste production or to maximise its treatment and use in order to reduce its quantity and harmfulness are part of the bioeconomy model promoted by the European Union. In addition, with careful energy management, it is possible to use energy from other renewable sources that are inextricably linked to the advantages of rural locations (e.g., wind or hydroelectric power stations, as well as biogas and biomass). An example that illustrates this point well is the use of photovoltaic cells in rural areas with a high number of sunny days. The installed photovoltaic panels provide a source of energy that is independent of other energy suppliers, thus allowing economic activity to be carried out in an environmentally friendly manner. The use of renewable energy sources by agricultural production entities contributes to increasing the sustainability of agricultural production, to increasing the self-sufficiency of entities in the sphere of energy supply, which reduces the economic risk of doing business.

\subsection{New Technologies as a Basis for New Location Trends in Agriculture}

Taking into account the fact that agricultural enterprises are in terms of technological advancement similar to industrial and service enterprises, the application of modern technologies in their activity is also of significance. This type of technology requires an adequate supply of energy to be secured, as well as a high level of energy security.

Despite the fact that agriculture is perceived as a traditional branch of the economy, modern technologies are being used in it with great success [16]. Key enabling technologies have been presented by the European Commission [17]. Among these, there are solutions based on nanotechnology [18], micro-technology [19], and technologies derived from life sciences. Agricultural enterprises can develop genetically modified food. This issue is admittedly very controversial [20] because the impact of genetic modification on the entire food chain is not fully known yet. However, without the work of geneticists in agriculture, it would not be possible to achieve improvements in the functional traits of many crop and livestock species, and consequently to reduce world hunger. Thus, the literature presents both positive and negative effects of GM foods [21]. Agricultural production units dealing with the genetics and breeding of crops and livestock may have similar location 
requirements to those of research and development units accompanying industrial or service activities.

Another new technology being used in agriculture is artificial intelligence in the context of agriculture automation [22] and getting value in agriculture [23]. Modern technologies related to connectivity are also important, for example related to the use of mobile phones [24], especially SMS information [25]. Another new technology is the Internet of Things [26], also in the context of sustainable rural development [27]. They contribute to a significant acceleration of information flows in modern managed farms through artificial intelligence based solutions. One example is computer control of physical and chemical parameters of livestock habitat. Other new technologies related to agriculture that can be mentioned here include precision agriculture [28] (considering factors influencing the adoption of precision agriculture technologies [29]) and Industry 4.0 [30].

Modern technologies are therefore finding more and more widespread use especially in agriculture in highly economically developed countries, where human labour has long been replaced by machines. An investment in an agricultural enterprise by a foreign investor may therefore need to take into account not only traditional factors of agricultural development and distribution [31]. This is particularly important for entrepreneurs who are diversifying their business activities. Consequently, they can invest not only in agricultural real estate, but also in industry or services that are linked to agricultural activity through the value chain. This is a feature that significantly distinguishes agricultural enterprises from individual farms. These farms are bound to households and not to industrial or service enterprises. All of this makes it necessary to learn about the method of assessing location advantages for agricultural economic entities, not only from the theoretical point of view, but also from the practical one.

To conclude, the specificity of the location requirements of agricultural enterprises compared to individual farms lies in the following elements:

- The large scale of agricultural production within individual agricultural enterprises.

- Greater opportunities and the associated benefits of using modern technologies.

- Cooperation with research facilities in the event of specialisation in plant and/or animal breeding.

- More frequent ownership and organisational links with industrial and/or commercial entities.

Agricultural enterprises depend on the energy factor because of:

- Greater dependence on energy supplies, due to the large scale of production and greater mechanisation of work than on traditional individual farms.

- Greater opportunities to use distributed renewable energy sources in a closed loop system.

\subsection{The Essence of Investment Attractiveness of Regions}

It is worth noting that in the literature the concept of investment attractiveness functions both in relation to enterprises [32], including agricultural enterprises [33], as well as spatial units. The subject of the research in this study was investment attractiveness of spatial units. There are numerous scientific elaborations in the literature on investment attractiveness of spatial units, but there is no unambiguous definition of this concept. A number of studies examine investment attractiveness of spatial units of various taxonomic levels (e.g., countries, regions, communes) without providing a concrete definition of this concept. In such a situation, investment attractiveness is often interpreted as a set of factors, e.g., geographic, economic, natural, political, social, the knowledge of which enables an investor to imagine the possibility of investing in a given country, region, or industry [34]. The multitude of factors influencing the level of investment attractiveness testifies to the multifaceted nature of this concept.

In a general sense it can be stated that investment attractiveness is the ability to induce investors to choose a region as a location for an investment [35]. According to E. Czerwieniec, investment attractiveness can be understood as a set of advantages of a given place (country, region), as certain areas show relatively better conditions for investment activity 
than others [36]. A similar interpretation of the concept of investment attractiveness is presented by T. Kalinowski, who states that it is a combination of location-specific advantages which can be achieved in the course of business activity and result from the specific features of the area in which the activity takes place [37]. Other researchers understand investment attractiveness as the purposefulness of making capital investments in the expansion and technical reconstruction of operating enterprises, defined as potential investment objects [38]. Investment attractiveness is also considered as a combination of signs, factors and conditions affecting the intensity of investment inflows [39], and as a system of existing opportunities, and measures affecting the demand for investment in a particular location or industry [40]. Investment attractiveness for agro-industrial production requires the creation of appropriate conditions (e.g., economic-financial, organisational-regulatory, and social) aimed at minimising the investment risk, which consequently contributes to increasing the investment value [41].

To sum up, investment attractiveness can be understood as the possibilities of satisfying the expectations of investors investing in a given region. Due to the fact that investor's satisfaction can be considered from the point of view of the locational advantages of a given place as well as the expected effects of an investment, two types of investment attractiveness are distinguished, i.e., potential investment attractiveness and actual investment attractiveness. Whereas actual investment attractiveness concerns the expected effects of an investment - it is the ability of a region to absorb financial and physical capital in the form of an investment [42]; and potential investment attractiveness of regions is understood as a set of regional location-specific advantages, which influence the attainment of the investor's objectives [43]. On the basis of literature studies, it has been demonstrated that there is no unambiguous and universally accepted definition of investment attractiveness in the literature. To sum up the above considerations, it should be stated that investment attractiveness is a multifaceted notion.

The subject of research in this study was potential investment attractiveness. The starting point is an analysis of the locational advantages of a place, understood as the elements of the geographical environment accumulated in a given part of space (natural, human, cultural resources, etc.), which become locational factors if they constitute the grounds for the investor's locational decision. Hence, for a particular enterprise, only those location advantages are relevant which at the same time constitute important location factors for that enterprise.

The concept of location factors was introduced to the literature by Alfred Weber. According to this author's concept, the location factor is a precisely defined benefit in the form of a reduction in production costs associated with conducting industrial activity in a precisely specified location (the transport factor was fundamental, and the labour and agglomeration factors were modifying) [44]. It should be noted that, in the modern economy, the scope of location factors has expanded and their role has been re-evaluated [45].

Thus, currently in the literature there are many divisions of location factors, among others a division into factors forcing investment (strategic) and encouraging investment (institutional) [46], factors stimulating to undertake activity, factors de-stimulating (discouraging) to undertake activity and factors that are indifferent [47], or a division into environmental, spatial, economic, sociocultural, political, legal-administrative, and technicaltechnological factors [48]. In addition, a distinction is made between hard factors (objectivethey directly affect the enterprise's operations and are easily measurable) and soft factors (subjective-they are difficult to measure or estimate, but play an important role in the operation of the enterprise as they shape the investment environment) [49]. When making location decisions, investors should consider the specifics of the location and incorporate various elements, such as earnings management [50].

It is worth noting that the issues related to investment attractiveness are often considered in the literature in the context of an inflow of foreign direct investment, which is related to the progressing processes of globalisation, the development of new forms of integration of economic entities and the formation of corporate structures. In the literature, 
investment attractiveness of spatial units is relatively often analysed in various taxonomic scales, i.e., national [51], regional [52], and local [53].

Investment attractiveness of cities [54] and, to a lesser extent, of rural areas [55], is relatively often examined. The researchers are probably less interested in the issue of investment attractiveness of rural areas due to the fact that they are characterised by a significantly lower economic and social potential in comparison with urban areas, where the accumulation of economic activity takes place. However, due to the fact that in the modern economy the location factors considered important are evolving, it should be stressed that rural areas can offer potential investors important advantages, e.g., in the form of the quality of the natural environment, and a greater supply of free land for investment than in cities [56]. Studies on investment attractiveness of rural areas most often concern location factors characteristic for various types of service and industrial activities, which is connected with the idea of multifunctional development of rural areas and creation of non-agricultural jobs. In literature it is relatively rare to find studies focusing on investment attractiveness of rural areas for agricultural activity.

Therefore, taking into account the above scientific discussion on the essence of investment attractiveness, the authors propose to apply a definition of potential investment attractiveness understood as a set of regional location advantages that influence achieving investors' goals (such as costs of running a business, sales revenues, net return on investment, and investment's competitiveness) [57]. These are the elements of the geographical environment accumulated in a given part of space (natural, human, cultural resources, etc.), which become locational factors if they constitute the grounds for the investor's locational decision. Hence, for a particular enterprise, only those location advantages are relevant, which, at the same time, constitute important location factors for that enterprise. Location advantages important for agricultural enterprises include not only socioeconomic characteristics but also natural features of the location environment.

\section{Materials and Methods}

Empirical analyses were based on indices of potential investment attractiveness of local government units for Section A businesses based on the methodology developed by the team led by H. Godlewska-Majkowska within the framework of statutory research conducted at the Collegium of Business Administration of the Warsaw School of Economics [58]. The analysis of potential investment attractiveness for Sections A businesses was conducted on two taxonomic levels, i.e., on the regional level—for all Polish voivodeships (16 units) and on the local level—for all rural counties (314 units). Urban counties were excluded from the analyses due to their urban nature [59]. (Since 1 January, 1999, Poland has had a three-tier administrative (territorial) division, under which the Polish territory has been divided into voivodeships, then into counties (including municipalities with the status of cities with county rights), and the smallest units-communes. As of 1 January, 2021, the administrative division of Poland included: 16 voivodeships, 314 counties (comprising several or more neighbouring communes-so-called rural counties), and 66 cities with county rights (a county can also be a spatial unit consisting of one city with county rights)).

The data for calculating the potential investment attractiveness index for businesses classified under Section A was obtained from the Central Statistical Office (GUS) and the Institute of Soil Science and Plant Cultivation in Puławy (IUNG) (data concerning the assessment of agricultural production space). All data are for 2019. The research methods used for this article are the weight-correlation method and cartographic analysis.

The weight-correlation method [60] used in this article makes it possible to standardise the individual input variables through the use of standardisation of the variables which avoids the problem of comparability of the sub-measures. It consists in transforming the univariate variables into pseudo univariate variables and further the set of pseudo univariate indices into a synthetic measure. The pseudo univariate indices make up microclimates and the microclimates make up the synthetic index of potential investment attractiveness. 
This article presents a proposal for calculating investment attractiveness indicators for agricultural enterprises in two variants-one at the regional and one at the local level. This is dictated by the different level of availability of statistical data-more statistical data are available at the regional level than at the local level. The research procedure is the same in both cases.

The research procedure consisted of the following steps:

- Selection of input variables for investment attractiveness assessment.

- Determination of the type of variables (stimulant or destimulant).

- Standardization of input variables.

- Division of variables into microclimates.

- Selection of microclimate weights to be included in the final index.

- The iterative part of calculation of the final index of investment attractiveness.

- Definition of final indicators of investment attractiveness.

- Division of statistical units into classes of investment attractiveness.

In the first step, statistical data for investment attractiveness assessment for regional and local levels were selected and transformed into input indices, taking into account the size of the studied statistical units (per capita, unit area, etc.).

In the second step, for the purpose of evaluating investment attractiveness, the variables, which unambiguously constitute the stimulants or destimulants of investment attractiveness, were used, i.e.:

- Destimulant (D): if the level of the variable arises, the potential attractiveness of a region will rise too.

- Stimulant (S): if the level of the variable arises, the potential attractiveness of a region will shrink.

In this step, some of the data that did not allow a clear assignment to stimulant or destimulant was also rejected.

In the third step, the input variables were standardised based on the following formulas.

- For stimulants:

$$
x_{i j}^{\prime}=\frac{x_{i j}-x_{\min . j}}{x_{\max . j}-x_{\min . j}} \times 100
$$

- For destimulants:

$$
x_{i j}^{\prime}=\frac{x_{\max . j}-x_{i j}}{x_{\max . j}-x_{\min . j}} \times 100
$$

where:

$j$-number of the next attribute sequential number of the spatial unit.

$x_{i j}^{\prime}$-normalised $j$-variable in $i$-spatial unit.

$x_{i j}$-value of $j$-variable in $i$-spatial unit.

$x_{\min . j-\text { minimum of } j \text {-variable. }}$

$x_{\text {max.j-maximum of } j \text {-variable. }}$

In the fourth step, the input variables were divided into microclimates corresponding to the main factors of the location of agricultural enterprises. The number of microclimates and the list of input variables constituting them were determined according to access to statistical data. For the study of investment attractiveness for Section A enterprises at the regional level, 61 variables were used, while a total of 36 variables were used for the analyses at the local level. For analysis at the regional level, these variables were grouped into eight microclimates: i.e., energy, labour resources, technical infrastructure, social infrastructure, market, administration, agricultural production intensity, and microclimate-quality and determinants of agricultural production. At the local level, this included 7 microclimates, as, due to the lower availability of statistical data at this taxonomic level, the intensity of agricultural production as well as quality and conditions of agricultural production 
microclimates were abandoned, and the agricultural values microclimate consisting of one index (i.e., quality of agricultural productive area) was introduced.

The table below presents input variables for evaluating potential investment attractiveness of agricultural enterprises at the regional level (voivodeship) in Poland (PAI A REGION), which form particular microclimates, together with their character (stimulant/destimulant) (Table 1).

Table 1. Input variables for estimating potential investment attractiveness of Section A businesses at regional level (voivodeships) in Poland in 2019 (PAI A REGION).

\begin{tabular}{|c|c|c|}
\hline No. & Microclimate/Input Variables & Character \\
\hline \multicolumn{3}{|c|}{ Microclimate-Energy } \\
\hline 1. & $\begin{array}{l}\text { Heat energy produced per year from the treatment of landfill gas in degassing installations per } \\
\qquad 1000 \text { inhabitants }\end{array}$ & S \\
\hline 2. & $\begin{array}{l}\text { Electrical energy produced per year from the treatment of landfill gas in degassing installations } \\
\text { per } 1000 \text { inhabitants }\end{array}$ & S \\
\hline 3. & Electricity consumption in rural areas per 1 inhabitant & S \\
\hline 4. & Piped gas consumption in rural households per 1 inhabitant & S \\
\hline 5. & Fluctuation of gas consumption in rural households per 1 inhabitant & $\mathrm{D}$ \\
\hline 6. & Gas users in rural areas as \% of total population & S \\
\hline 7. & Distribution network in $\mathrm{km}$ per $100 \mathrm{~km}^{2}$ —gas distribution infrastructure in rural areas & S \\
\hline 8. & Density of heat transmission and distribution network in rural areas in $\mathrm{km} / \mathrm{km}^{2}$ & S \\
\hline 9. & Electricity production from renewable sources per 1 inhabitant & S \\
\hline 10. & Electricity consumption in agriculture per 100 ha of arable land & S \\
\hline 11. & Rural electricity consumption including consumption for agricultural production per 1 inhabitant & $\mathrm{S}$ \\
\hline 12. & Expenditure on fixed assets for environmental protection-energy saving per 1 inhabitant & S \\
\hline 13. & $\begin{array}{l}\text { Municipal waste management-weight of collected municipal waste for thermal treatment with } \\
\text { energy recovery per } 1000 \text { inhabitants (tons/person) }\end{array}$ & S \\
\hline
\end{tabular}

\section{Microclimate-Labour Resources}

\begin{tabular}{|c|c|c|}
\hline 14. & Percentage of the population in non-productive age per 100 people in productive age & $\mathrm{D}$ \\
\hline 15. & Labour force participation rate & S \\
\hline 16. & Population in post-productive age per 100 people in pre-productive age & $\mathrm{D}$ \\
\hline 17. & Share of population in productive age & S \\
\hline \multicolumn{3}{|c|}{ Microclimate-Technical Infrastructure } \\
\hline 18. & $\%$ share of the population covered by the water supply system & S \\
\hline 19. & $\%$ share of dwellings connected to the gas pipeline & S \\
\hline 20. & $\%$ share of the population covered by the sewage system & S \\
\hline 21. & Density of the water supply network in $\mathrm{km}$ per $100 \mathrm{~km}^{2}$ & S \\
\hline 22. & Density of the gas pipeline network in $\mathrm{km}$ per $100 \mathrm{~km}^{2}$ & S \\
\hline 23. & Density of the sewage network in $\mathrm{km}$ per $100 \mathrm{~km}^{2}$ & $\mathrm{~S}$ \\
\hline 24. & $\begin{array}{l}\text { Sludge previously stored (accumulated) on the premises of the treatment plant-as of } 31.12 \text { (tons } \\
\text { of dry matter) per } 1000 \text { inhabitants }\end{array}$ & $\mathrm{D}$ \\
\hline 25. & Waste generated during the year-disposed of/waste generated during the year & S \\
\hline 26. & Share of treated wastewater in wastewater requiring treatment & S \\
\hline
\end{tabular}


Table 1. Cont.

\begin{tabular}{|c|c|c|}
\hline No. & Microclimate/Input Variables & Character \\
\hline \multicolumn{3}{|c|}{ Microclimate-Social Infrastructure } \\
\hline 27. & Medical practices in the countryside and in the city per 100,000 inhabitants & S \\
\hline 28. & Number of health care facilities per 100 thousand inhabitants & $\mathrm{S}$ \\
\hline 29. & Number of pharmacies per 100 thousand inhabitants & $\mathrm{S}$ \\
\hline 30. & Usable floor area of apartments per capita & $\mathrm{S}$ \\
\hline 31. & The number of viewers in stationary cinemas per 100 inhabitants & S \\
\hline 32. & Number of visitors to museums with branches per 1000 inhabitants & S \\
\hline 33. & Length of bicycle paths per 1000 inhabitants & S \\
\hline \multicolumn{3}{|c|}{ Microclimate-Market } \\
\hline 34. & Population density per $\mathrm{km}^{2}$ & S \\
\hline 35. & Value added per person employed in Section A & S \\
\hline 36. & Share of value added in Section A in relation to share of those employed in Section A & S \\
\hline \multicolumn{3}{|c|}{ Microclimate-Administration } \\
\hline 37. & Funds for financing own tasks obtained from other sources per capita & S \\
\hline 38. & Share of own revenues in total revenues & S \\
\hline 39. & $\begin{array}{l}\text { Expenditure on municipal management and environmental protection and on safety and fire } \\
\text { protection per capita }\end{array}$ & S \\
\hline \multicolumn{3}{|c|}{ Microclimate_Agricultural Production Intensity } \\
\hline 40. & Value of final agricultural production per 1 ha of arable land (PLN/ha) & S \\
\hline 41. & Share of agricultural commodity production in the final agricultural production (\%) & S \\
\hline 42. & $\begin{array}{l}\text { Livestock (cattle, sheep, goats, horses, pigs, poultry) in livestock units (LSU) per } 1 \text { ha of arable } \\
\text { land }\end{array}$ & S \\
\hline 43. & Livestock production per ha of arable land-milk (litres) & S \\
\hline 44. & Livestock production per 1 ha of arable land-slaughter livestock converted into meat (kg) & S \\
\hline 45. & Crop production-yield per ha一total cereals $(\mathrm{dt} / \mathrm{ha})$ & S \\
\hline 46. & Agricultural crops-yield per hectare-field vegetables + tree fruit + berry fruit (dt/ha) & S \\
\hline 47. & Other agricultural crops-yield per ha & S \\
\hline 48. & Purchase of products per 1 ha of arable land-basic cereals & S \\
\hline 49. & Purchase of products per 1 ha of arable land-potatoes & S \\
\hline 50. & Purchase of products per 1 ha of arable land-sugar beets & S \\
\hline 51. & Purchase of products per 1 ha of arable land-cow's milk & S \\
\hline 52. & $\begin{array}{c}\text { Mineral fertiliser consumption (nitrogen, phosphorus, potassium) per } 1 \text { ha of arable land in good } \\
\text { cultivation }(\mathrm{kg} / \mathrm{ha})\end{array}$ & S \\
\hline 53. & Calcium fertiliser consumption per 1 ha of arable land in good cultivation $(\mathrm{kg} / \mathrm{ha})$ & S \\
\hline \multicolumn{3}{|c|}{ Microclimate-Quality and Determinants of Agricultural Production } \\
\hline 54. & Samples disqualified as \% of total tested-fruit & $\mathrm{D}$ \\
\hline 55. & Share of arable land area in certified organic farms in the total arable land (\%) & S \\
\hline 56. & $\begin{array}{l}\text { Expenditure on fixed assets for environmental protection-protection and restoration of use } \\
\text { value of soil, protection of underground and surface water per } 1 \text { ha of total area }\end{array}$ & S \\
\hline
\end{tabular}


Table 1. Cont

\begin{tabular}{ccc}
\hline No. & Microclimate/Input Variables & Character \\
\hline 57. & Share of devastated and degraded land which has been rehabilitated or developed for \\
agricultural purposes in the total area of arable land (\%) & $\mathrm{S}$ \\
\hline 58. & Share of area of fires on meadows, stubble and wasteland in the total area of arable land (\%) & $\mathrm{D}$ \\
\hline 59. & Quality index for agricultural production area & $\mathrm{S}$ \\
\hline 60. & Share of agricultural tax revenue in tax revenues & $\mathrm{S}$ \\
\hline 61. & Arable land area per inhabitant & $\mathrm{S}$ \\
\hline
\end{tabular}

Note: the quality index for agricultural production area consists of the following components: soil quality and agricultural suitability, agroclimate, land topography, and soil water relations [61]. Source: own study based on data from the Central Statistical Office (GUS) and the Institute of Soil Science and Plant Cultivation in Puławy (IUNG).

Due to the lower availability of statistical data at the county level in Poland, a slightly smaller number of input variables were used to assess the potential investment attractiveness for agricultural enterprises on the local level (counties) (PAI A LOCAL) (Table 2).

Table 2. Input variables for assessing potential investment attractiveness of Section A businesses on the local level (counties) in Poland in 2019 (PAI A LOCAL).

\begin{tabular}{|c|c|c|}
\hline No. & Microclimate/Input Variables & Character \\
\hline \multicolumn{3}{|c|}{ Microclimate-Energy } \\
\hline 1. & $\begin{array}{l}\text { Electrical energy produced per year from the treatment of landfill gas in degassing installations } \\
\text { per } 1000 \text { inhabitants }\end{array}$ & S \\
\hline 2. & Electricity consumption in rural areas per 1 inhabitant & S \\
\hline 3. & Piped gas consumption in rural households per 1 inhabitant & S \\
\hline 4. & Fluctuation of gas consumption in rural households per 1 inhabitant & $\mathrm{D}$ \\
\hline 5. & Gas users in rural areas as \% of total population & S \\
\hline 6. & Distribution network in $\mathrm{km}$ per $100 \mathrm{~km}^{2}$ —gas distribution infrastructure in rural areas & S \\
\hline 7. & Density of heat transmission and distribution network in rural areas in $\mathrm{km} / \mathrm{km}^{2}$ & S \\
\hline \multicolumn{3}{|c|}{ Microclimate-Labour Resources } \\
\hline 8. & Percentage of the population in non-productive age per 100 people in productive age & $\mathrm{D}$ \\
\hline 9. & Labour force participation rate & S \\
\hline 10. & Internal permanent migration rate per 1000 inhabitants & S \\
\hline 11. & Population in post-productive age per 100 people in pre-productive age & $\mathrm{D}$ \\
\hline 12. & Share of population in productive age & $\mathrm{S}$ \\
\hline No. & Microclimate/Input Variables & Character \\
\hline \multicolumn{3}{|c|}{ Microclimate-Technical Infrastructure } \\
\hline 13. & $\%$ share of the population covered by the water supply system & S \\
\hline 14. & $\%$ share of dwellings connected to the gas pipeline & $\mathrm{S}$ \\
\hline 15. & $\%$ share of the population covered by the sewage system & S \\
\hline 16. & Density of the water supply network in $\mathrm{km}$ per $100 \mathrm{~km}^{2}$ & S \\
\hline 17. & Density of the gas pipeline network in $\mathrm{km}$ per $100 \mathrm{~km}^{2}$ & S \\
\hline 18. & Density of the sewage network in $\mathrm{km}$ per $100 \mathrm{~km}^{2}$ & $S$ \\
\hline 19. & $\begin{array}{l}\text { Sludge previously stored (accumulated) on the premises of the treatment plant-as of } 31.12 \text { (tons } \\
\text { of dry matter) per } 1000 \text { inhabitants }\end{array}$ & $\mathrm{D}$ \\
\hline 20. & Waste generated during the year—disposed of/waste generated during the year & S \\
\hline 21. & Share of treated wastewater in wastewater requiring treatment & S \\
\hline
\end{tabular}


Table 2. Cont.

\begin{tabular}{|c|c|c|}
\hline \multicolumn{3}{|c|}{ Microclimate-Social Infrastructure } \\
\hline 22. & Medical practices in the countryside and in the city per 100,000 inhabitants & S \\
\hline 23. & Number of health care facilities per 100 thousand inhabitants & S \\
\hline 24. & Number of pharmacies per 100 thousand inhabitants & S \\
\hline 25. & Usable floor area of apartments per capita & S \\
\hline 26. & The number of viewers in stationary cinemas per 100 inhabitants & S \\
\hline 27. & Number of visitors to museums with branches per 1000 inhabitants & S \\
\hline 28. & Length of bicycle paths per 1000 inhabitants & S \\
\hline \multicolumn{3}{|c|}{ Microclimate-Market } \\
\hline 29. & Population density per $\mathrm{km}^{2}$ & $S$ \\
\hline 30. & Revenue of commune budgets from personal income tax (PIT) per 1000 inhabitants & S \\
\hline 31. & Share of social welfare expenditure in commune budget expenditure & $\mathrm{D}$ \\
\hline 32. & Agricultural tax revenue per inhabitant & S \\
\hline \multicolumn{3}{|c|}{ Microclimate-Administration } \\
\hline 33. & Funds for financing own tasks obtained from other sources per 1 inhabitant & S \\
\hline 34. & Share of own revenues in total revenues & S \\
\hline 35. & $\begin{array}{l}\text { Expenditure on municipal management and environmental protection and on safety and fire } \\
\text { protection per } 1 \text { inhabitant }\end{array}$ & S \\
\hline 36. & $\begin{array}{l}\text { Microclimate-Agricultural Values } \\
\text { Quality index for agricultural production area }\end{array}$ & $S$ \\
\hline
\end{tabular}

Note: the quality index for agricultural production area consists of the following components: soil quality and agricultural suitability, agroclimate, land topography, and soil water relations [61]. Source: own study based on data from the Central Statistical Office (GUS) and the Institute of Soil Science and Plant Cultivation in Puławy (IUNG).

In the case of the regional level, the agricultural factors were included in two microclimates according to the availability of data allowing for additional identification of the microclimates: agricultural production intensity and quality and determinants of agricultural production. However, in the case of the investment attractiveness index at the local level, the availability of data allowed only the use of the Quality index for agricultural production area developed by IUNG (hence, the original name of this index as a microclimate was retained). Therefore, when this method is used at the local level by researchers from other countries, we recommend the use of analogous indices describing the valorisation of agricultural production space, developed by relevant scientific institutions. In both tables, the energy microclimate was introduced as an original proposal that allows to demonstrate the influence of the energy factor on the investment attractiveness of the regions, which is directly related to the research hypothesis H1. Due to the different availability of statistical data, the structure of the energy microclimate at the regional level consists of a greater number of input variables than compared to the local level.

In the fifth step, the microclimate weights included in the final index were selected. For each microclimate, an aggregated vector of standardised sums was determined according to the formula:

$$
q_{i, n}=\frac{1}{m_{n}} \times \sum_{j=1}^{m_{n}} x_{i j}^{\prime}
$$

where:

$q_{i, n}$-evaluation of $n$-microclimate in $i$-spatial unit.

$m_{n}$-number of explanatory variables comprising the microclimate in question.

$n$-number of microclimate.

The sixth step is the iterative part of the calculation of the final index of investment attractiveness. It consisted in the calculation of the output correlation vector $r_{n}$ (using Pearson's correlation coefficient) between the value of each microclimate and the vector of microclimates sums. The correlation vector $r_{n}^{\prime}$ between the microclimate and the vector 
of microclimate sums was then iteratively determined until the changes of correlation coefficients between following iterations became irrelevant.

The seventh step was to identify the final index of investment attractiveness. The final correlation coefficients, $r_{n}^{\prime}$, thus determined, constitute weights for the individual microclimates, reflecting their strength of influence on the synthetic index, according to the formula:

$$
P A I_{i}=\frac{1}{n} \sum_{k=1}^{n} r_{n}^{\prime} \times q_{i, n}
$$

where:

$P A I_{i}$-summary evaluation.

$q_{i, n}$ - evaluation of $n$-microclimate in $i$-spatial unit.

$n$-number of microclimate.

$r_{n}^{\prime}$-final correlation between each microclimate and the sum of all microclimates.

By an iterative route, multiple recalculations yielded stabilised correlation coefficients between individual microclimates and the aggregated potential investment attractiveness index (PAI A). According to the methodology used in the article, the presented correlation indices are the weights with which the individual microclimates are accounted for in the aggregated investment attractiveness index (according to formula (4)). These indices are presented in the figures below.

The results presented in Figures 1 and 2 allow to assess the strength of the relationship between the energy factor and the investment attractiveness of territorial units for agricultural enterprises, which is the basis for testing the research hypothesis H1. The results also enable the identification of other important localization factors. It is important that the preliminary research results allow the identification of factors with significant importance (the correlation index should be at least 0.6). In addition, none of the correlation indices should be negative. However, if any of the correlation indices has a negative value, the input variables should be checked and the whole testing procedure should be repeated.

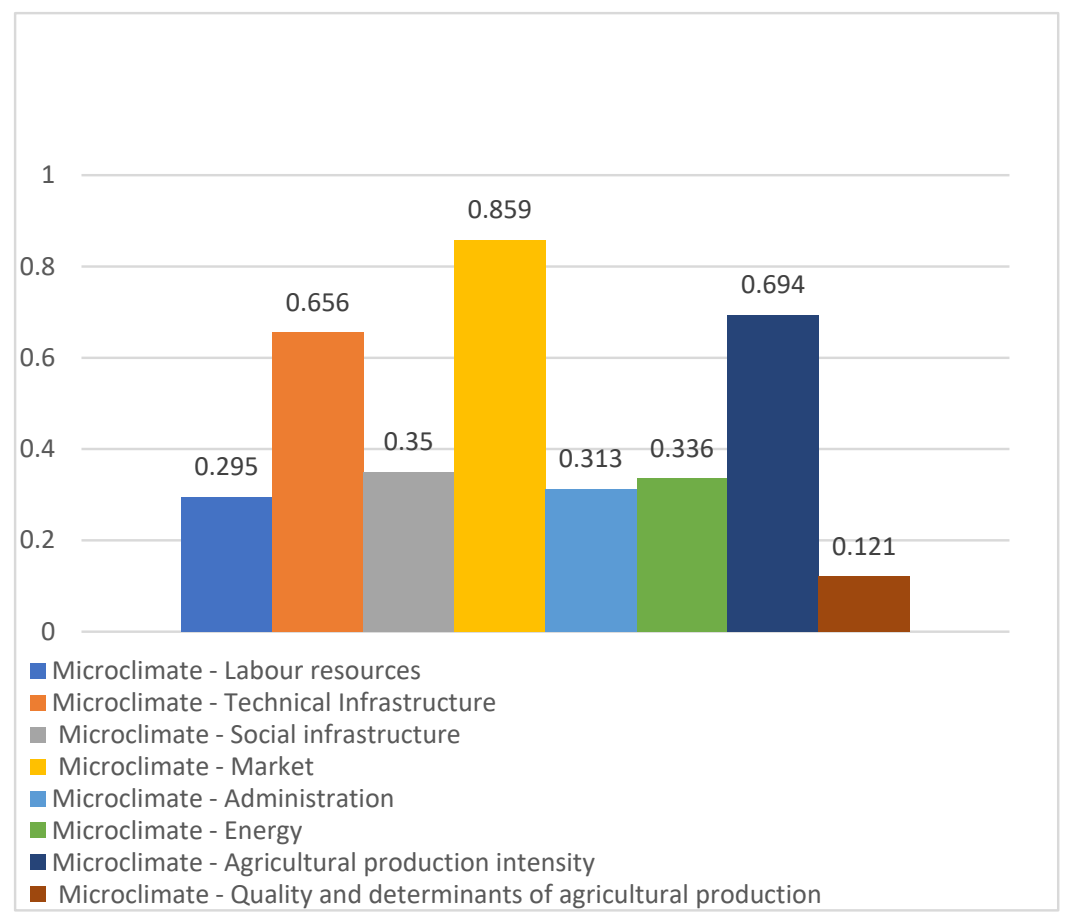

Figure 1. Correlation coefficient between individual microclimates and the aggregated potential investment attractiveness index at the regional level (PAI A REGION) in Poland. Source: own research. 


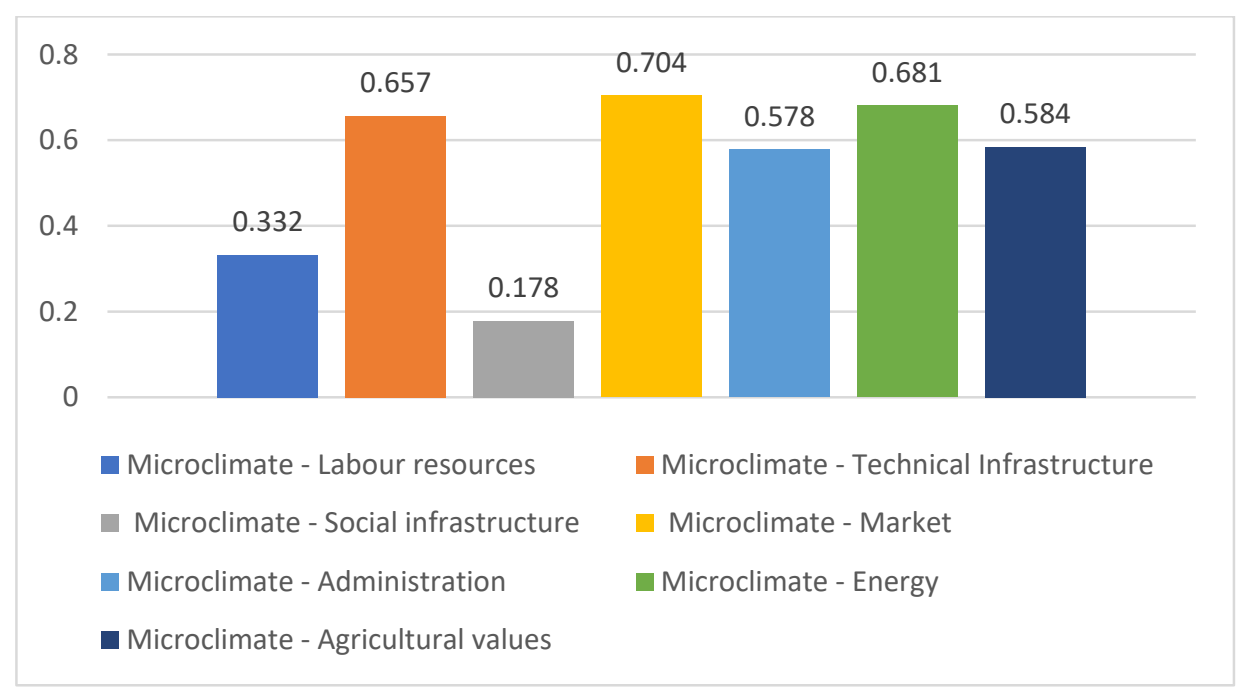

Figure 2. Correlation coefficient between individual microclimates and the aggregated potential investment attractiveness index at the local level (PAI A LOCAL) in Poland. Source: own research.

In the eighth step, the statistical units were classified into investment attractiveness classes. The PAI index determined on the basis of the presented procedure constitutes a basis for the division of spatial units into classes A-F, where class A stands for the highest investment attractiveness, while class $\mathrm{F}$ stands for the lowest investment attractiveness. The class range was determined in accordance with formula (5). In other words, class A contains spatial units with the PAI level higher than sum of average and standard deviation derived from the PAI measure (inclusively). Respectively, class B ranges from sum of average and half of standard deviation (inclusively) to sum of average and standard deviation (exclusively).

$$
W_{P A I}=\left\{\begin{array}{c}
A: \quad P A I_{i} \geq \bar{x}_{P A I}+S_{P A I} \\
B: \quad P A I_{i} \geq \bar{x}_{P A I}+0.5 \times S_{P A I} \wedge P A I_{i}<\bar{x}_{P A I}+S_{P A I} \\
C: \quad P A I_{i} \geq \bar{x}_{P A I}<\bar{x}_{P A I}+0.5 \times S_{P A I} \\
D: \quad P A I_{i} \geq \bar{x}_{P A I}-0.5 \times S_{P A I} \wedge P A I_{i}<\bar{x}_{P A I} \\
E: \quad P A I_{i} \geq \bar{x}_{P A I}-S_{P A I} \wedge P A I_{i}<\bar{x}_{P A I}-0.5 \times S_{P A I} \\
F: \quad P A I_{i}<\bar{x}_{P A I}-S_{P A I}
\end{array}\right.
$$

where:

$A-F$-investment attractiveness classes, where $A$ stands for the highest level of investment attractiveness, and $F$ for the lowest level of investment attractiveness.

$P A I$ - potential investment attractiveness index.

$\bar{x}_{P A I}$-average of $P A I$ for each level type of regions.

$S_{P A I}$-standard deviation of $P A I$ for each level type of regions.

\section{Results}

The spatial analysis is based on the cartograms presented in Figures 3 and 4 . The first refers to the spatial differentiation of potential investment attractiveness of NUT2 level regions for investment in agriculture (Section A). As shown in Figure 3, voivodeships characterised by the highest investment attractiveness (Class A) are those that are provisioning regions for big cities and/or characterised by long-term food surpluses, obtained as a result of high level of agricultural culture, with a tradition of food export and above-average level of production intensity. That is why the list of highest ranked voivodeships opens with the Greater Poland voivodeship (investment attractiveness class A), which fulfils all of the above mentioned conditions. The Mazowieckie and Pomorskie voivodeships were also highly rated (Class A). The Zachodniopomorskie and Kujawsko-Pomorskie voivodeships 
also achieved high class B. Voivodeships: Dolnoslaskie, Opolskie, Warminsko-Mazurskie, and Slaskie are also ranked above average (class $\mathrm{C}$ ).

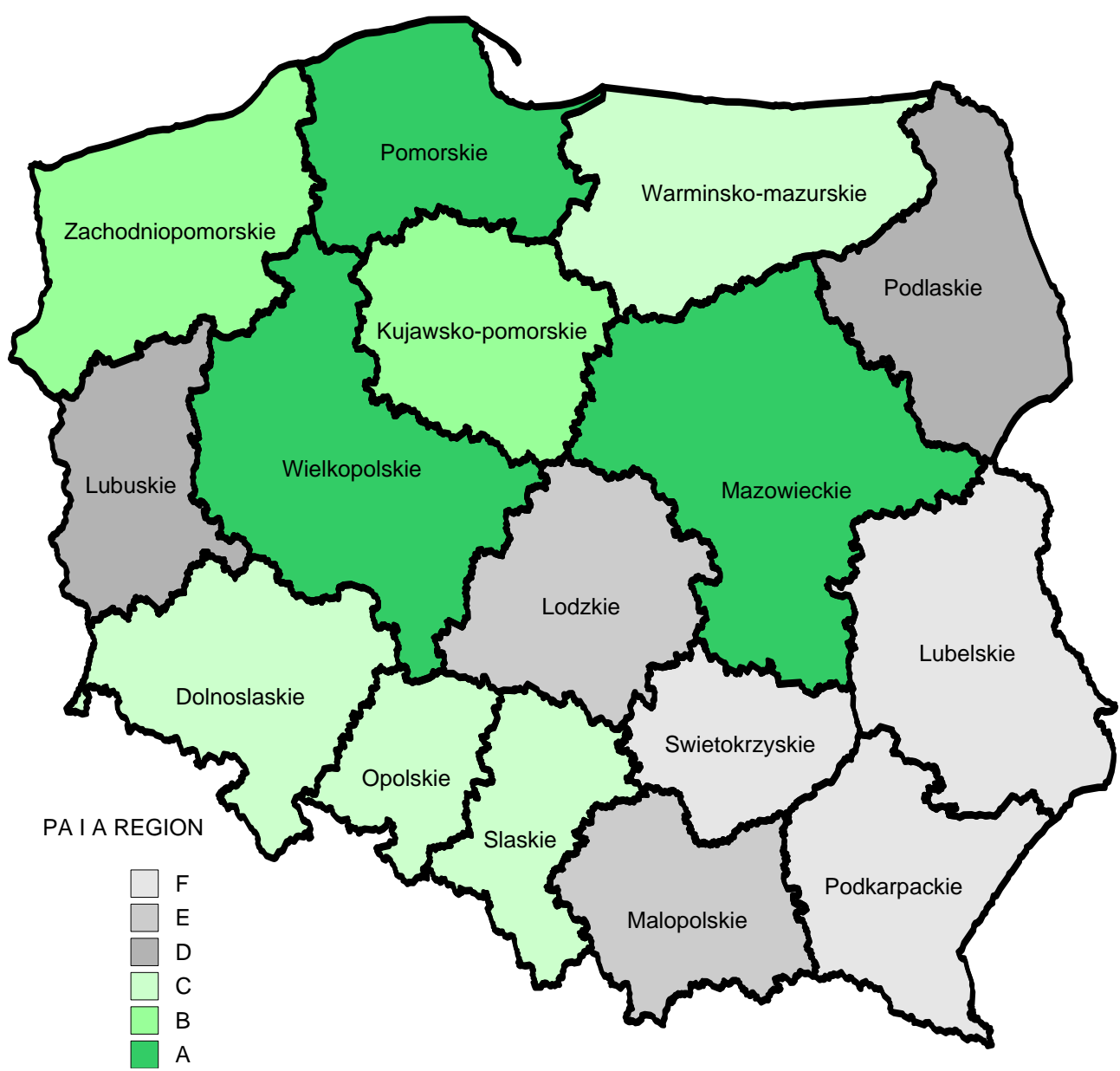

Figure 3. Spatial diversification of the potential investment attractiveness index for Section A enterprises at the regional level (voivodeships) in Poland in 2019 (PAI A REGION). More about the regions of Poland: https://www.paih.gov.pl/publications/regions. (accessed on 30 April 2021). Source: own research (using the program Map Viewer).

The specificity of investment attractiveness of regions for enterprises in agriculture is already expressed in higher assessment of investment attractiveness of regions in which in the past agriculture was dominated by state farms or production cooperatives. Agricultural enterprises are already located in such regions as Wielkopolskie $(10,641$ economic entities out of 70,347 in Poland in 2019), Mazowieckie (8301), Pomorskie (4117), and Slaskie voivodeships (4833). The majority of the regions, due to their location in western Poland, used to provide provisions not only for the home regions, but also as a provisioning area for Germany, especially in the period before the Second World War. The legacy of this period is an extensive road network, a higher level of agricultural culture and better education of the rural population compared to eastern Poland.

Due to the fact that regions show great internal differentiation, the analysis of investment attractiveness at the regional level provides a source of directional guidance in the choice of location options. Therefore, a valuable supplement to the regional analysis is the presentation of indices based on the analysis of investment attractiveness on a local scale (counties), which is presented in Figure 4.

As can be seen from Figure 4, the regions with the highest attractiveness classes are often located in the provisioning zones of large cities, which is particularly evident in the provisioning zones of Warsaw (districts surrounding Warsaw), also the suburban areas of 
the agglomerations of Kraków, Wrocław, and other cities serving as regional capitals. The role of natural factors is also evident, as well as that of wholesale or industrial markets in regions located in the Lubelskie, Podkarpackie, and Zachodniopomorskie voivodeships. In addition, attention is drawn to the southern provisioning zone of the Slaskie voivodeship (Silesia) that is more distant from the immediate vicinity.

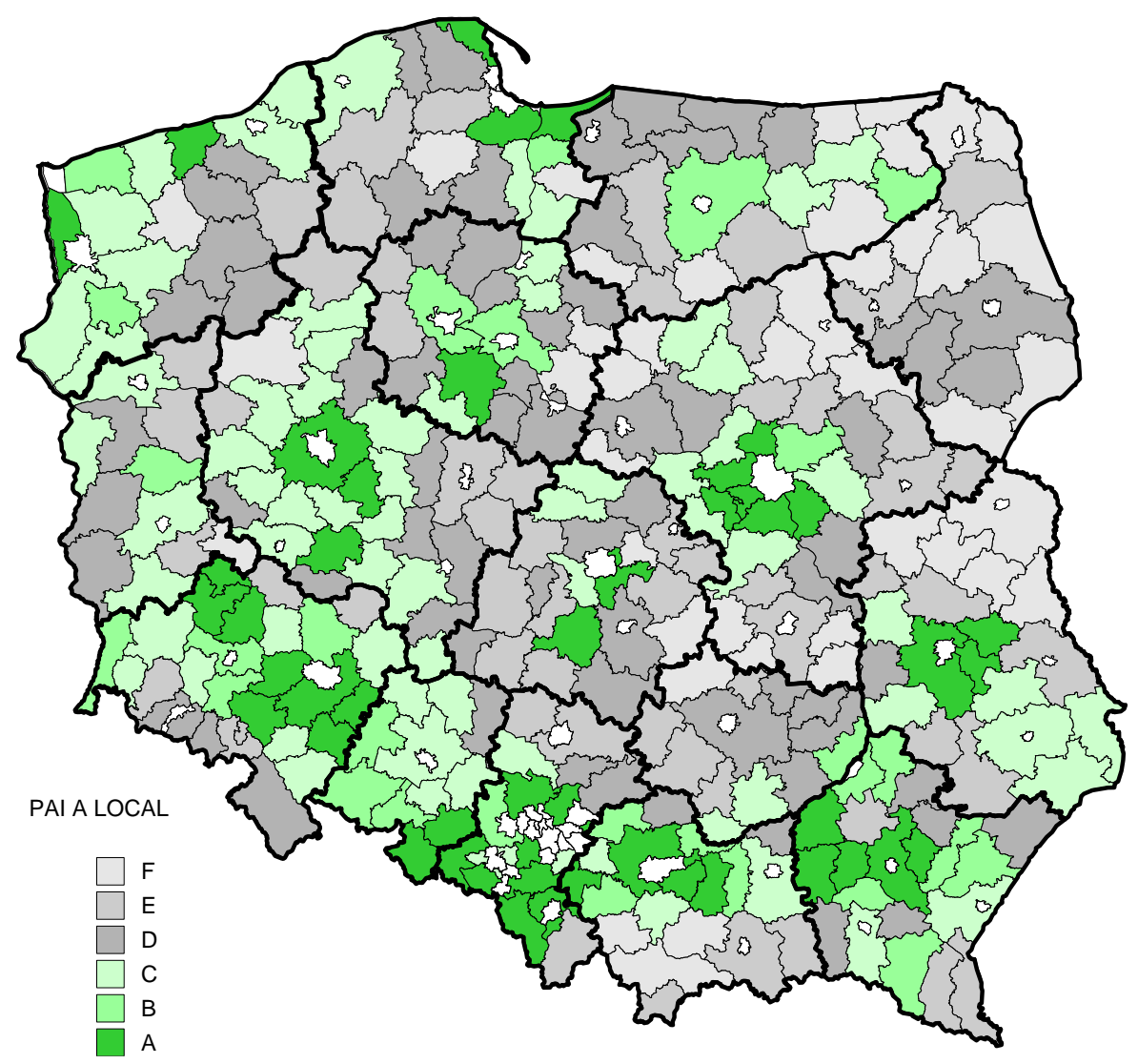

Figure 4. Spatial diversification of the potential investment attractiveness index for Section A enterprises at the local level (counties) in Poland in 2019 (PAI A LOCAL). White colour means cities with county rights, which are not covered by the study due to the lack of agricultural functions. Source: own research (using the program Map Viewer).

Analyses carried out using econometric and cartographic methods indicate that there is a directly proportional (positive) relationship between the investment attractiveness of regions and energy management, which is reflected in the high correlation coefficient between the energy microclimate and the aggregated investment attractiveness index at a local level (0.681), and not so high at regional level (0.336)—see Figures 1 and 2. This confirms the research hypothesis $\mathrm{H} 1$ : there is a positive relationship between the energy factor and the investment attractiveness of regions for enterprises from Section A. This relationship is stronger at the local level, which is due to the reduced level of differentiation of locational assets at the local scale compared to the regional scale.

Taking into account the fact that the assessment of the energy factor comprised components describing access to energy infrastructure as well as variables describing the rationality of the use of energy sources, it can also be concluded that good energy supply conditions and the rationalisation of energy management favour the creation of wellorganised supply chains for agriculture. This applies both to the supply of inputs for agricultural production and to the distribution of agricultural products. The existence of such locational advantages is indicated by the high rating of the energy microclimate in voivodeships such as: Slaskie (which results from the specialisation in coal and steel 
production associated with the traditions of hard coal mining and steel production, as well as the largest urban complex in Poland). In addition, the Małopolska voivodeship received a high rating, which is related to the presence of the second largest city in Poland after Warsaw, i.e., Krakow. The city of Krakow is an important centre with good electricity supply conditions as a consequence of its industrial specialisation. The lowest rating was given to the Warminsko-Mazurskie voivodeship, which is located in north-eastern Poland, far from large Polish cities.

At the county level, counties that are part of the suburban zones of Polish urban agglomerations, as well as individual industrial centres, were rated highest in terms of energy values. The following counties belong to the most prominent ones in terms of energy values favourable for agriculture: Pruszkowski, Grodziski, Warszawski Zachodni, Legionowski, Piaseczyński, which surround the capital city of Poland and at the same time constitute its direct provisioning base. In addition, counties surrounding other large cities in Poland, notably Krakow, Wroclaw, Poznan, and Szczecin, received high scores based on this criterion. Interestingly, these cities form a network of regional level centres which occur in Poland with a regularity corresponding to the assumptions of Thünen's theory or the creator of the theory of central places, W. Christaller. This can therefore be linked to the type of hierarchical settlement network specific to Central Europe, which was the starting point for the formulation of assumptions about isotropic space in location theories.

Both the cartographic analysis and the level of location indices demonstrate the high validity of Thünen's rings theory. This is evidenced by the high weight of the market microclimate in the regional and local model of potential investment attractiveness. (Figures 1 and 2). In addition, the distribution of the most attractive spatial units shows a strong correlation with the location of markets both created by large cities and their provisioning zones.

To summarise: based on the analysis of the spatial diversification of the proposed index, it can be concluded that:

- $\quad$ The most attractive regions for investment in the agricultural sector are those with well-developed market outlets and well-equipped with technical infrastructure, characterised by a high level of agricultural culture,

- The historical factor and the new location arrangement of agricultural enterprises formed as a result of privatisation of state and cooperative farms have a great influence on the formation of location advantages for agricultural enterprises,

- The spatial diversification of investment attractiveness for agricultural enterprises is explained by the spatial diversification of settlement network distribution, in particular, the proximity of big cities, and also shows a relation to the spatial diversification of natural values (the quality of agricultural production space.

The next step was to analyse the results of the evaluation of the investment attractiveness and the actual distribution of agricultural enterprises in Poland. The analysis of correlation indices between the number of Section A enterprises operating in individual voivodeships and the potential attractiveness index (PAI REGION) showed a high correlation (0.75). The deeper analysis of the data also showed a significant importance of specialization in livestock production as a factor influencing the actual distribution of agricultural enterprises at the regional level. At the local level, this correlation could not be found due to the lack of data on the production specialization of each region.

It is worth emphasising that the Polish regions can serve as an example of a location environment for agricultural enterprises representative of other countries and regions in Central and Eastern Europe. This is the result of similar historical determinants of agricultural development in these countries, as well as contemporary trends. These include the determinants associated with the privatisation of agricultural state enterprises, as well as similar demographic problems in rural areas. Furthermore, the example of Poland allows for generalisations due to the fact that the long-term effects of the loss of sovereignty (the partitions of Poland) persist to this day in the Polish economic space, including in particular the division of space between three countries, i.e., Germany, Russia, and Austria. 
Consequently, the settlement network and agricultural development were shaped by the settlement and agricultural policies of the three countries. This has led to significant disparities in Poland's regional development, which remain to this day.

\section{Discussion}

The issue of investment attractiveness of regions for Section A enterprises (agriculture, forestry, hunting and fishing) is relatively rarely studied in the literature. It is tackled, for example, in the Russian literature, but the conditions of the agricultural sector in Russia (operating under international economic sanctions and import substitution) are different from those typical of free-competitive economies. In addition, sometimes the analyses lack a proposal for an aggregate measure of investment attractiveness of regions for agricultural enterprises, they are descriptive in nature presenting the volume of production of agricultural crops, indicators of land use and livestock and some indicators of the socioeconomic development [41].

M. Vasilchenko, E. Derunova, in turn, analyse investment attractiveness in terms of agricultural organization, rather than spatial units. They define investment attractiveness as "ability to realise its innovative potential by attracting additional sources of investment and introducing new innovative forms and methods of investment policy" [62] (p. 513). The authors propose to use for assessment of investment attractiveness of agriculture an integrated indicator based on evaluation of innovative, scientific, intellectual, production and technological potential, natural resources, as well as taking into account the risks of financial and economic activity [62]. Their research approach refers to the entrepreneurial and sectoral context of institutional theory, not to the location theory.

To assess the investment attractiveness of the agro-industrial complex of the Lipetsk region (using a balanced scorecard), it was proposed factors characterizing the level of investment attractiveness of regional agribusiness are grouped into ten groups: the current state of investment activity, the potential of the agro-industrial complex, the group of indicators of staffing, production factors, the innovative development opportunities of the agro-industrial complex, the group of infrastructural factors of the investment process, the financial conditions for investment, the institutional conditions for making investments, consumer restrictions and social restrictions. One of the factors belonging to the group of infrastructural factors of the investment process was the level of energy supply, but it was not explained how this level should be measured at regional or local level [63].

Ukrainian researchers suggest using SWOT analysis to assess the investment attractiveness of the region for the agricultural sector, which is a useful proposition for analysing the investment attractiveness of a single selected region (it was presented on the basis of Cherkasy region) [64].

The literature also suggests internal and external factors determining investment attractiveness of agricultural enterprises at the national level without taking into account regional and local differences [65]. With regard to the quantitative measurement of investment attractiveness, the analyses look at the country's place in world attractiveness rankings and the level of the Total Support Estimate (TSE), which presents the amount of gross transfers received from taxpayers and consumers so that the government can implement policies to support agriculture [65]. In the research on investment potential of agriculture in Kazakhstan, the correlation-regression model was used, in which indicators that influence investment attractiveness of agriculture include: employed population in agriculture, agriculture expenses form state budget, GDP, gross output of agriculture, and number of agricultural enterprises [66]. The analysis of the Investment Attractiveness of the Agricultural Sector in Republic of Moldova was based mainly on financial data, i.e., financial statements of commercial banks and other financial institutions determining the involvement of these entities in investments in agriculture [67]. This approach also does not provide a basis for analysing the spatial differentiation of investment attractiveness, including the energy factor. 
On the basis of the conducted literature research, it can be concluded that the issue of investment attractiveness of regions for agricultural enterprises has not yet been the subject of in-depth scientific analyses, which indicates the existence of a research gap in this area.

The presented research streams on the investment attractiveness of regions or the agricultural sector do not provide guidelines for measuring investment attractiveness as a spatially diversified phenomenon, nor do they provide insights into the current location factors of agricultural enterprises.

This gap is both theoretical (connected with a small number of scientific publications on investment attractiveness of regions for agricultural enterprises, which implies poor recognition of the problem) and methodological. Moreover, the lack of recognition in the literature of the influence of the energy factor on the investment attractiveness of regions for agricultural enterprises, as well as the lack of emphasis on the significance of this factor in shaping the level of investment attractiveness of regions was also demonstrated. This study contributes to reducing the identified research gap.

Therefore, the conducted analysis allows for generalizations regarding the directions of changes in spatial structure not only in the Polish economic area, but also in other European regions that underwent the system transformation in the 1990s. The long-term effects of the urbanization processes, denaturalization of food consumption, and increasing energy consumption are visible. The current importance of location factors for agricultural enterprises is related to historically-shaped sales markets created by large agglomerations, but natural values, access to technical infrastructure, and energy are also important at the local level.

It should be noted that the research results obtained have certain limitations. They are mainly related to the lower availability of data at the local level than at the regional level. Therefore, in this study, the construction of the investment attractiveness index at the local level is based on a smaller number of input variables than at the regional level. However, due to the smaller area (i.e., greater internal similarity), the investment attractiveness indices for local units are subject to a smaller cognitive error than the regional ones. Therefore, at the local level, the dependence of investment attractiveness on factors related to the proximity of markets, the quality of natural factors, access to technical infrastructure and the energy factor is more visible.

On the other hand, the investment attractiveness index at the regional level is based on a larger number of input variables than at the local level. While a limitation of the regional index is the greater internal differentiation of regions due to their larger area. Therefore, the regional indices take into account the internal differentiation of the location values for agriculture to a lesser extent.

Another limitation is the frequency of collecting detailed statistical data on agriculture based on the Agricultural Census, which is conducted every 10 years in all EU Member States. Currently, data from the last census, conducted in 2020, is not yet available. Moreover, it should be noted that some of the indices used to characterise agriculture are a generalisations of data collected on the basis of a selected sample, while maintaining its representativeness.

It should be stressed that the research method used has both advantages and disadvantages. The advantages of the adopted research method include the elimination of mutually correlated features, as well as taking into account the impact strength of individual diagnostic features on the final result without the need for the authors of the analysis to assign ranks subjectively. Omitting the ranks of sub-variables could risk distorting the assessment of investment attractiveness of spatial units.

The limitation of the weight correlation method is the lack of comparability of the computational results for the time series, since the vector of weights is different for each period of analysis. In addition, like most methods based on multicriteria analysis, this method also has drawbacks in the form of: discretion in the selection of input variables, lack of full access to spatial data and incomparability of data for units with changed administrative boundaries. 
Another methodological limitation is the availability of regional and local databases, which varies across countries. The proposed model uses the quality index for agricultural production area developed by the IUNG (the index is available in Poland for all territorial units at both regional and local levels). Due to the fact that its development requires the assessment of soil quality, topography, and agroclimate, analogous indices may not be available for other European regions. Therefore, the possibility of valorisation of investment attractiveness for agricultural enterprises may be hampered by the limited availability of data.

Despite these limitations, the weight-correlation method is also gaining interest among researchers who create multi-criteria indices for example to assess lake trophic status [68] or monitoring and managing aquatic environment quality in regional eutrophic lakes around the world [69]. However, this is hardly the case for spatial analyses, especially those carried out at different taxonomic levels taking into account sectoral specificities.

Further research directions should be associated with the expansion of the scope of diagnostic variables and the verification of the statistical model with the application of other methods, which will allow the study of this phenomenon for European regions (including their verification based on the actual course of capital inflow into the sector of agricultural enterprises, taking into account the attractiveness class and specialization of production regions and development paths). It may be particularly interesting to look for development paths of regions with agricultural specialization that combine agricultural specialization with sustainable development and bioeconomy as a basis for complex regional development.

\section{Conclusions}

Current location trends in the activities of agricultural enterprises are still closely linked to the distribution of markets. This is especially true of enterprises similar in character to industrial enterprises, taking into account the use of equipment, which makes it possible to increase the scale of operations. This means that the J.H. Thünen agricultural location theory is still applicable. In this theory, the city was the main element of the organization of the spatial structure of agricultural production. Taking into account the growing importance of electricity in agricultural production-the availability, prices, and cost of obtaining energy should be included in the land rent.

In the location theory, attempts have been made to create a model that would allow optimization of decisions on the location of entrepreneurial activity. However, there is still no model approach that would allow for rationalisation of location decisions under the conditions of the global economy and the creation of extensive spatial structures by agricultural enterprises. There is, therefore, a need to develop a model that would allow the investment attractiveness of regions to be assessed at different taxonomic levels.

In light of the research results presented in this study, it can be concluded that the application of the valorisation model of investment attractiveness of regions developed by the authors allows the simultaneous comparison of any number of statistical units at the regional level at the scale of a country or a group of countries, subject to a harmonised statistical reporting system. On the basis of the model used for the location analysis of investment attractiveness of Polish regions, it can be stated that the location advantages and location factors can be explained on the basis of the path dependence theory. The region, which in the past was a food base for large markets, still has high investment attractiveness for agricultural activity due to the historically high level of agricultural culture and specialization in livestock breeding.

The research model based on the proposed sub-aggregates (microclimates) separately for the regional and local level, subject to the availability of data, is an original solution that so far has no counterparts in the literature. The correlation-weight method is also relatively rarely used. The results of the presented analysis indicate the validity of its wider application in spatial studies. An important argument in favour of its application is the 
achievement of non-modal solutions, which are nowadays the subject of exploration in decision-making analyses based on multi-criteria models.

When looking for model approaches, it is worth verifying the results of in-depth research on the example of a single country, provided that it is representative of spatial structures that go beyond the political borders of a single country. It is worth emphasising that the Polish regions can serve as an example of a location environment for agricultural enterprises representative of other countries and regions in Central and Eastern Europe. This is the result of the similarity between the historical and contemporary conditions of agricultural development in these countries.

Further work on finding links between the location decisions made and the investment attractiveness of regions for agricultural enterprises requires the standardisation of basic concepts. Due to the fact that there is no unambiguous, universally accepted definition of investment attractiveness in the literature. Investment attractiveness is a multifaceted notion, which translates into a lack of unanimity in its definition. Moreover, it has been proven that the issue of investment attractiveness of regions for agricultural enterprises has not been the subject of in-depth scientific analyses so far, which indicates the existence of a research gap in this field of theoretical and methodological nature. This is the achievement of the first specific objective (O1).

The authors therefore propose to define investment attractiveness as: understood as a set of regional location advantages that influence achieving investors' goals (such as costs of running a business, sales revenues, net return on investment and investment's competitiveness), understood as the elements of the geographical environment accumulated in a given part of space (natural, human, cultural resources, etc.), which become locational factors if they constitute the grounds for the investor's locational decision. Hence, for a particular enterprise, only those location advantages are relevant, which, at the same time, constitute important location factors for that enterprise. In the case of locational advantages, not only the socioeconomic characteristics, but also the natural features of the locational environment will be important for agricultural enterprises.

The author's potential investment attractiveness index for agricultural enterprises (PAI A) proposed in the article was enhanced in comparison with other proposals of the $\mathrm{H}$. Godlewska-Majkowska's team by adding the following microclimates: energy, agriculture values (index for local units), as well as quality and determinants of agricultural production microclimates, and microclimate of agricultural production intensity (regional level). This is the achievement of the second specific objective (O2).

The applied components of the assessment of energy values, while showing a directly proportional relationship between investment attractiveness and the energy factor, indicate that the use of renewable energy sources by agricultural production entities contributes to increasing the sustainability of agricultural production, to increasing the self-sufficiency of entities in the sphere of energy supply, which reduces the economic risk of doing business. Due to the high internal differentiation of locational values at the regional level, this relationship is weaker in the case of NUTS2 regions, while it is stronger for local units. This confirms the research hypothesis (H1), which indicates that the main research objective has been achieved.

The results of the research can be used by local government units to develop and implement regional and local agricultural development programmes, as well as to shape investment attractiveness for agricultural enterprises. They can provide valuable practical guidance on what type of actions should be implemented to achieve synergies. This is particularly important in view of the fact that investments by agricultural enterprises can support the socioeconomic development of areas traditionally relying on the agricultural sector, in order to ensure sustainable regional and local development based on the bioeconomy.

Further research directions may be based on an attempt to generalise the location theory approach, which is based on the use of elements of the path dependence theory and complex region theory. 
Author Contributions: Conceptualization, H.G.-M. and A.K.; Methodology, H.G.-M. and A.K.; Software, H.G.-M.; Validation, H.G.-M. and A.K.; Formal, Analysis, H.G.-M. and A.K.; Investigation, H.G.-M. and A.K.; Resources, H.G.-M. and A.K.; Data Curation, H.G.-M. and A.K.; Writing-Original Draft Preparation, H.G.-M. and A.K.; Writing-Review and Editing, A.K.; Visualization, H.G.-M.; Supervision, H.G.-M.; Project Administration, A.K.; Funding Acquisition, H.G.-M. and A.K. All authors have read and agreed to the published version of the manuscript.

Funding: The APC was funded by SGH Warsaw School of Economics (budget line KNoP/S19/14/19) and the University of Life Sciences, Faculty of Agrobioengineering (grant number RKZ/S/29/2021).

Institutional Review Board Statement: Not applicable.

Informed Consent Statement: Not applicable.

Data Availability Statement: Not applicable.

Conflicts of Interest: The authors declare no conflict of interest.

\section{References}

1. Thünen, J.H. Der Isolierte Staat in Beziehung auf Landwirtschaft und Nationalökonomie; Perthes: Hamburg, Germany, 1826.

2. Angelsen, A. Forest Cover Change in Space and Time: Combining the Von Thünen and Forest Transition Theories; World Bank Policy Research Paper 4117; World Bank: Washington, DC, USA, 2007.

3. Mäki, U. Realism and the Nature of Theory: A Lesson from J H von Thünen for Economists and Geographers. Environ. Plan. A Econ. Space 2004, 36, 1719-1736. [CrossRef]

4. O'Kelly, M.; Bryan, D. Argicultural location theory: Von Thunen's contributions to economic geography. Prog. Hum. Geogr. 1996, 20, 457-475. [CrossRef]

5. Fujita, M. Thünen and the New Economic Geography. Reg. Sci. Urban. Econ. 2012, 42, 907-912. [CrossRef]

6. Sinclair, R. Von Thünen and urban sprawl. Ann. Am. Geogr. Assoc. 1967, 57, 72-87. [CrossRef]

7. Wigier, M. Czas i przestrzeń w długookresowym rozwoju rolnictwa i obszarów wiejskich—ujęcie retrospektywne. J. Agribus. Rural Dev. 2012, 2, 263-272.

8. Roos, A.; Eggers, J.; Mark-Herbert, C.; Lindhagen, A. Using von Thünen rings and service-dominant logic in balancing forest ecosystem services. Land Use Policy 2018, 79, 622-632. [CrossRef]

9. Wagner, K. Funktionen der Landwirtschaft in Stadtnahen Grünstrukturen. EU-COST Aktion C11 Greenstructure and Urban Planning; AWI Bundesanstalt für Agarwirtschaft: Vienna, Austria, 2005.

10. Sroka, W. Resources and use of agricultural land in Polish cities according to chosen theories of location of agricultural production. Acta Sci. Pol. Oeconomia 2015, 14, 135-147.

11. Kuciński, K. Geografia Ekonomiczna. Zarys Teoretyczny; SGH: Warszawa, Poland, 2000; pp. 76-77.

12. Pepliński, B. Location of Cows and Pigs in Suburban Areas of Polish Metropolitan Centers. Sustainability 2020, 12, 2619. [CrossRef]

13. Maroušek, J.; Maroušková, A.; Kůs, T. Shower cooler reduces pollutants release in production of competitive cement substitute at low cost. Energy Sources Part A 2020, 1-10. [CrossRef]

14. Maroušek, J.; Bartoš, P.; Filip, M.; Kolář, L.; Konvalina, P.; Maroušková, A.; Moudrý, J.; Peterka, J.; Šál, J.; Šoch, M.; et al. Advances in the agrochemical utilization of fermentation residues reduce the cost of purpose-grown phytomass for biogas production. Energy Sources Part A Recover. Util. Environ. Eff. 2020. [CrossRef]

15. Maroušek, J.; Rowland, Z.; Valášková, K.; Král, P. Techno-economic assessment of potato waste management in developing economies. Clean Technol. Environ. 2020, 22, 937-944. [CrossRef]

16. Ugochukwu, A.I.; Phillips, P.W.B. Technology Adoption by Agricultural Producers: A Review of the Literature. In From Agriscience to Agribusiness. Innovation, Technology, and Knowledge Management; Kalaitzandonakes, N., Carayannis, E., Grigoroudis, E., Rozakis, S., Eds.; Springer: Cham, Switzerland, 2018.

17. European Commission. Key Enabling Technologies. Available online: https://ec.europa.eu/info/research-and-innovation/ research-area/industrial-research-and-innovation/key-enabling-technologies_en (accessed on 26 February 2021).

18. Chen, H.; Yada, R. Nanotechnologies in agriculture: New tools for sustainable development. Trends Food Sci. Technol. 2011, 22, 585-594. [CrossRef]

19. Nazzaro, F.; Fratianni, F.; Coppola, R. Microtechnology and nanotechnology in food science. In Green Technologies in Food Production and Processing; Boye, J., Arcand, Y., Eds.; Springer: Boston, MA, USA, 2012.

20. Uzogara, S.G. The impact of genetic modification of human foods in the 21st century: A review. Biotechnol. Adv. 2000, 18, 179-206. [CrossRef]

21. Islam, R.; Parvin, A.; Billah, M.M.; Islam, M.; Imran, M.A.S.; Sarker, R.K.; Uddin, M.E.; Alam, M.S.; Abedin, M.Z. Assessment of the Effects of Genetically Modified (GM) Foods: A Brief Study on Health and Environmental Concerns. J. Mater. Environ. Sci. 2020, 11, 1676-1688.

22. Jha, K.; Doshi, A.; Patel, P.; Shah, M. A comprehensive review on automation in agriculture using artificial intelligence. Artif. Intell. Agric. 2019, 2, 1-12. [CrossRef] 
23. Smith Matthew, J. Getting value from artificial intelligence in agriculture. Anim. Prod. Sci. 2018, 60, 46-54. [CrossRef]

24. Gupta, A.; Ponticelli, J.; Tesei, A. Information, Technology Adoption and Productivity: The Role of Mobile Phones in Agriculture. National Bureau of Economic Research; NBER Working Paper Series, Working Paper 27192; National Bureau of Economic Research: Cambridge, MA, USA, 2020.

25. Fafchamps, M.; Minten, B. Impact of SMS-based Agricultural Information on Indian Farmers. World Bank Econ. Rev. 2012, 26, 383-414. [CrossRef]

26. Tzounis, A.; Katsoulas, N.; Bartzanas, T.; Kittas, C. Internet of Things in agriculture, recent advances and future challenges. Biosyst. Eng. 2017, 164, 31-48.

27. Dlodlo, N.; Kalezhi, J. The internet of things in agriculture for sustainable rural development. In Proceedings of the International Conference on Emerging Trends in Networks and Computer Communications (ETNCC), Windhoek, Namibia, 17-20 May 2015; pp. 13-18.

28. Zhang, N.; Wang, M.; Wang, N. Precision agriculture-A worldwide overview. Comput. Electron. Agric. 2002, 36, 113-132. [CrossRef]

29. Tey, Y.S.; Brindal, M. Factors influencing the adoption of precision agricultural technologies: A review for policy implications. Precis. Agric. 2012, 13, 713-730.

30. Trivelli, L.; Apicella, A.; Chiarello, F.; Rana, R.; Fantoni, G.; Tarabella, A. From precision agriculture to Industry 4.0: Unveiling technological connections in the agrifood sector. Br. Food J. 2019, 121, 1730-1743. [CrossRef]

31. Pechenevsky, V.; Zakshevsky, G. Prospects for the spatial development of agricultural production in the region. In Proceedings of the International Scientific and Practical Conference on Agrarian Economy in the Era of Globalization and Integration, Moscow, Russia, 25-28 October 2018.

32. Akhmetshin, E.M.; Artemova, E.I.; Vermennikova, L.V.; Shichiyakh, R.A.; Prodanova, N.A.; Kuchukova, N.M. Management of Investment Attractiveness of Enterprises: Principles, Methods, Organization. Int. J. Appl. Bus. Econ. Res. 2017, 15, 71-82.

33. Davydenko, N.; Skrypnyk, H. Evaluation Methods of Investment Attractiveness of Ukrainian Agricultural Enterprises. Balt. J. Econ. Stud. 2017, 3, 103-107. [CrossRef]

34. Vologdin, E.V. Methodical and Practical Aspects of Assessing the Investment Attractiveness of the Region, Novosibirsk. Available online: www.searc.rsl.ru (accessed on 8 January 2021).

35. Gawlikowska-Hueckel, K.; Umiński, S. Ocena Konkurencyjności Województw; Instytut Badań nad Gospodarką Rynkową: Gdańsk, Poland, 2000; p. 7.

36. Czerwieniec, E. Bezpośrednie inwestycje zagraniczne w środowisku lokalnym. Zesz. Nauk. Pr. Katedr. Mikroekonomii Akad. Ekon. W Pozn. 2007, 94, 7-23.

37. Kalinowski, T. Atrakcyjność Inwestycyjna Województw i Podregionów Polski 2006; Instytut Badań nad Gospodarką Rynkową: Gdańsk, Poland, 2006; p. 13.

38. Shilov, E.; Kukhlenko, O.; Goyko, А. Методы Оценки Эффективности иПривлекательности ИнвестиционныхПроектов; Kitusa: Kiev, Ukraine, 1996; p. 14.

39. Jumaev, N.X.; Rakhmonov, D.A.; Sulaymanov, S.A. Ways to Attract Investment with Assessment of Investment Potential of the Regions. Int. J. Econ. Commer. Manag. 2019, 7, 664-673.

40. Ponin, A.S. Management of Investment Attractiveness in Region; RAGS: Moscow, Russia, 2000; p. 175.

41. Semin, A.; Kibirov, A.; Rassukhanov, U. Problems and Main Mechanisms to Increase Investment Attractiveness of Agricultural Production. Eur. Res. Stud. J. 2018, 21, 378-400. [CrossRef]

42. Godlewska-Majkowska, H. Atrakcyjność Inwestycyjna Polskich Regionów. W Poszukiwaniu Nowych Miar; Studia i Analizy Instytutu Przedsiębiorstwa, Oficyna Wydawnicza SGH: Warszawa, Poland, 2008.

43. Godlewska-Majkowska, H. Atrakcyjność Inwestycyjna Regionów Polski a Ksztattowanie Lokalnych i Regionalnych Specjalizacji Gospodarczych; Studia i Analizy Instytutu Przedsiębiorstwa, Oficyna Wydawnicza SGH: Warszawa, Poland, 2009.

44. Weber, A. Über den Standort der Industrien. I Teil, Reine Theorie des Standorts; Verlag von J. C. B. Mohr (Paul Siebeck): Tübingen, Germany, 1909.

45. Kramin, M.V.; Safiullin, L.N.; Kramin, T.V.; Timiryasova, A.V. Drivers of economic growth and investment attractiveness of Russian regions. Life Sci. J. 2014, 11, 526-530.

46. Zachorowska, A. Ryzyko Działalności Inwestycyjnej Przedsiębiorstw; PWE: Warszawa, Poland, 2006; pp. 115-116.

47. Dzikowska-Zawirska, J.; Włodarczyk-Guzek, W. Napływ zagranicznych inwestycji bezpośrednich ze szczególnym uwzględnieniem Łódzkiej Specjalnej Strefy Ekonomicznej. Acta Univ. Lodz. Folia Oeconomica 2002, 158, 53-83.

48. Budner, W. Lokalizacja Przedsiębiorstw. Czynniki Ekonomiczno-Przestrzenne i Środowiskowe; Wydawnictwo Akademii Ekonomicznej w Poznaniu: Poznań, Poland, 2003; pp. 28-30.

49. Dziemianowicz, W. Bezpośrednie Inwestycje Zagraniczne—Między Teoria a Praktyką; Regionalne Centrum Informacji Integracji Europejskiej przy Akademii Ekonomicznej w Krakowie: Kraków, Poland, 2002.

50. Kliestik, T.; Valaskova, K.; Nica, E.; Kovacova, M.; Lazaroiu, G. Advanced methods of earnings management: Monotonic trends and change-points under spotlight in the Visegrad countries. Oeconomia Copernic. 2020, 11, 371-400. [CrossRef]

51. Dorożyński, T.; Kuna-Marszałek, A. Investment Attractiveness. The Case of the Visegrad Group Countries. Comp. Econ. Res. 2016, 19, 119-140. [CrossRef] 
52. Valinurova, L.S.; Kazakova, O.B.; Sulimova, E.A. Evaluation of Investment Attractiveness and Prediction of Investment Volumes to the Region. Mediterr. J. Soc. Sci. 2015, 6, 371-379. [CrossRef]

53. Godlewska-Majkowska, H.; Perło, D. Zastosowanie metody wagowo-korelacyjnej i modelowania miękkiego do analizy atrakcyjności inwestycyjnej powiatów w Polsce. Zarządzanie I Finans. J. Manag. Financ. 2017, 15, 187-214.

54. Snieska, V.; Zykiene, I. City attractiveness for investment: Characteristics and underlying factors. Procedia Soc. Behav. Sci. 2015, 213, 48-54. [CrossRef]

55. Zarębski, P. Atrakcyjność inwestycyjna obszarów wiejskich w Polsce. Zesz. Nauk. Sggw Warszawie. Probl. Rol. Światowego 2012, 12, 169-178.

56. Komor, A. Atrakcyjność inwestycyjna obszarów wiejskich województwa lubelskiego. Zesz. Probl. Postępów Nauk Rol. 2009, 542, 1039-1046.

57. Godlewska-Majkowska, H.; Komor, A.; Turek, D.; Zaręski, P.; Czernecki, M.; Typa, M. Regional Investment Attractiveness 2016, Report Prepared for the Polish Information and Foreign Investment Agency at the Institute of Enterprise; Warsaw School of Economics: Warsaw, Poland, 2016. Available online: https://www.paih.gov.pl/publications/regions (accessed on 2 April 2021).

58. Godlewska-Majkowska, H. Atrakcyjność Inwestycyjna Regionów Polski Jako Źródło Przedsiębiorczych Przewag Konkurencyjnych; Studia i Analizy Instytutu Przedsiębiorstwa, Oficyna Wydawnicza SGH: Warszawa, Poland, 2012.

59. Central Statistical Office (GUS). Available online: www.stat.gov.pl (accessed on 5 February 2021).

60. Brzozowski, T.; Pogorzelski, W. Naturalne wartości wskaźników jakości, metoda wagowo-korelacyjna. Wiadomości. Statystyczne GUS 1992, 4, 42-44.

61. Quality Index for Agricultural Production Area (Wskaźnik Waloryzacji Rolniczej Przestrzeni Produkcyjnej-WWRPP), Institute of Soil Science and Plant Cultivation in Puławy (IUNG). Available online: http://onw.iung.pulawy.pl/specyficzne/wwrpp (accessed on 2 April 2021).

62. Vasilchenko, M.; Derunova, E. Factors of Investment Attractiveness of Russian Agriculture in the Context of Innovative Structural Adjustment. Sci. Pap. Ser. Manag. Econ. Eng. Agric. Rural Dev. 2020, 20, 511-522.

63. Esina, Y.L.; Stepanenkova, N.M. Methodology for Assessing Investment Attractiveness of AIC of the Lipetsk Region. Available online: https: / / www.elibrary.ru/item.asp?id=42869373 (accessed on 2 April 2021).

64. Davydenko, N.; Buriak, A.; Demianenko, I. Investment Attractiveness of Agricultural Sector of Ukrainian Region in Modern Conditions of Social and Economic Development. Balt. J. Econ. Stud. 2018, 4, 106-110. [CrossRef]

65. Kulynych, Y.M.; Shirinyan, L.V. The Investment Attractiveness of the Agricultural Sector of Ukraine. Економіка 2018, 12, 211-216.

66. Tankiyeva, A.K. Myth and Reality of Investment Attractiveness of Agriculture in Kazakhstan. Econ. Agric. $2016,6,149-155$.

67. Timofti, E.; Popa, D.; Petrascu, S.; Osborne, P. The Investment Attractiveness of the Agricultural Sector in Republic of Moldova in Terms of European Integration. Probl. World Agric. 2018, 18, 315-322.

68. Maofei, N.; Qiushi, G.; Siyue, L.; Zhikang, W.; Yunjie, W. Trophic state index linked to partial pressure of aquatic carbon dioxide in atypical karst plateau lake. Ecol. Indic. 2021, 120, 106912.

69. Liu, D.; Du, Y.; Yu, S.; Luo, J.; Duan, H. Human activities determine quantity and composition of dissolved organic matter in lakes along the Yangtze River. Water Res. 2020, 168, 115132. [CrossRef] [PubMed] 